\title{
The Optimization of Calcareous Fly Ash-Added Cement Containing Grinding Aids and Strength-Improving Additives
}

\author{
Gökhan Kaplan $\mathbb{D}^{1},{ }^{1}$ Sadık Alper Yildizel $\mathbb{D}^{\mathrm{D}},{ }^{2}$ Selçuk Memiş $\mathbb{D}^{3}{ }^{3}$ and Ali Uğur Öztürk ${ }^{4}$ \\ ${ }^{1}$ Kastamonu Vocational School, Kastamonu University, Kastamonu, Turkey \\ ${ }^{2}$ Engineering Faculty, Civil Engineering Department, Karamanoglu MehmetBey University, Karaman, Turkey \\ ${ }^{3}$ Engineering Faculty, Civil Engineering Department, Kastamonu University, Kastamonu, Turkey \\ ${ }^{4}$ Engineering Faculty, Civil Engineering Department, Manisa Celal Bayar University, Manisa, Turkey \\ Correspondence should be addressed to Gökhan Kaplan; gkaplan@kastamonu.edu.tr
}

Received 29 July 2017; Revised 30 October 2017; Accepted 9 November 2017; Published 28 January 2018

Academic Editor: Arnaud Perrot

Copyright (C) 2018 Gökhan Kaplan et al. This is an open access article distributed under the Creative Commons Attribution License, which permits unrestricted use, distribution, and reproduction in any medium, provided the original work is properly cited.

\begin{abstract}
This is an experimental study which explores the physical, mechanical, and economic factors involved in the production of type CEM II A-B/W cement. In this context, 4 cement additives were used in two different dosages ( 200 and $800 \mathrm{~g} / \mathrm{t})$. Class $\mathrm{C}$ fly ash was used for composite cement production at ratios of 5\%, 20\%, and 35\%. It was shown that Blaine fineness increases with the increasing fly ash content. The use of fly ash at ratios of $5 \%$ and $20 \%$ was not found to have any unfavorable effects on the compressive strength at the early days. It is found that the use of additive for improving the early-age strength is preferable when fly ash is used. It is possible to produce Class $52.5 \mathrm{~N}$ cement using additives to improve early strength and $20 \%$ fly ash. Loss in strength was observed in cement mortars produced using glycol-based grinding aid. Increasing the dosage of chemical additive also led to loss in strength due to nonhomogeneous distribution of hydration products. As a result, grinding fly ash with clinker and the use of cement chemicals contribute to the cement sector in terms of sustainability. It is possible to produce cements with improved mechanical properties especially with the use of $20 \%$ fly ash.
\end{abstract}

\section{Introduction}

Today, cement consumption in the world has reached up to a level of 4 billion tons/year. The power consumed during cement production is approx. $110 \mathrm{~kW} /$ ton, and around $30 \%$ of this power is used during raw material preparation phases and $40 \%$ is used in order to grind the cement clinker [1-3]. This power consumption rate leads to significant increase in costs especially in those regions where power is a rare commodity [4]. Along with the obligation to process increasingly larger quantities of ores containing finely disseminated minerals, our limited energy resources and the rising costs of energy present a challenge to the process engineer. One research route that has been explored for about half a century is the development of additives to the grinding mill feed that substantially improve the efficiency of grinding. Such additives are termed grinding aids. Grinding aids are used in order to reduce the electrostatic forces between cement particles and their agglomeration. Grinding aids most commonly consist of ethanolamines such as triethanolamine (TEA) and triisopropanolamine (TIPA) along with glycols such as diethylene glycol (DEG) and propylene glycol (PG) [5]. Grinding aids are not capable of preserving their original molecular structures after the grinding process. Moreover, grinding aids are absorbed on the cement particles in a way to alter the properties of fresh and hardened concrete [6]. For example, grinding aids reinforced with TIPA molecules increase the cement hydration reactions which allow for improved compressive strength [5]. Ramachandran reported that TEA retards hydration of $\mathrm{C}_{3} \mathrm{~S}$ and $\beta-\mathrm{C}_{2} \mathrm{~S}$ while resulting in a number of changes in the morphology and microstructure of the hydration products. Hydration of $\mathrm{C}_{3} \mathrm{~A}$ is accelerated in case of the use of TEA [7]. Helen and Ölmez have found that hydration and setting time of cement is prolonged when the ethanolamine concentration is increased [8]. Ichikawa et al. 
published findings suggesting that TIPA increases the hydration of limestone along with improving alite and ferrite hydration and that it thickens the interfacial transition zone (ITZ) between hydrated cement paste and aggregate particles [9]. Altun et al. showed that TIPA-based grinding aids, thanks to their operational benefits and properties to help improve quality, are more suitable for dry-mixed cement applications [10]. Zhang et al. analyzed the properties of polymer-based grinding aids (PGA). This study found that PGA has a significant effect on the particle size distribution of the cement and that this implies a rather narrower grading spectrum as the PGA dosage increases [11]. Li et al. used waste oil as grinding aid during cement grinding process. As a result, it was suggested that the use of waste oil as grinding aid in cement grinding process is economically and environmentally sustainable [12]. Zhang et al. used waste glycerin, industrial lignin, and molasses as grinding aids for composite cements. Results of the research showed that the grinding aids used improved mechanical properties of the composite cement while accelerating hydration [13]. A number of studies used PCEs as grinding aids. Results of these studies showed that the use of PCEs, when compared to TEA, improves the strength of the cement while offering the same grinding efficiency [14-16]. Sun et al. produced cement under laboratory conditions using polycarboxylatebased grinding aids. The use of polycarboxylate-based grinding aids during grinding process significantly improves the viscosity of cement paste while it did not have a significant negative effect on the other properties of cement [17]. Ghiasvand and Ramezanianpour produced composite cements with two and three components. They have also used limestone as one of these components. The authors suggested that the use of grinding aids is of utmost importance in order to produce high quality PLCs due to the agglomeration of limestone particles [18]. As a rule, the concentration range of the grinding aid used is very important in terms of the performance of cement. For example, $0.02 \%$ TEA addition to Portland cement acts as a setting accelerator, while $0.25 \%$ TEA addition acts as mild setting retarder, $0.5 \%$ TEA addition, on the other hand, acts as a setting retarder, and 1\% TEA addition acts as a strong setting accelerator [8].

The expectations on the properties of the concrete used in construction industry increase as the scale of the industrial production increases. Due to insufficient energy levels and natural resources, the demand for highperformance cement has gradually increased. A significant way to meet such demand is to produce high-performance cement, cement substitutes, and high-performance composites [19-21]. Recently, cement substitutes and composite cements have become increasingly available in concrete production [22]. Among some of the cement substitutes are fly ash which is a by-product of coal combustion, silica fume which is a by-product of ferrosilicon production process, and blast-furnace slag which is a waste produced during cast iron manufacturing. Fly ash is commonly known as a pozzolana with very poor hydraulic properties; however, it accelerates the hydration of cement thanks to its surface absorption effect and heterogeneous nucleation [23-25].
Therefore, fly ash may improve the mechanical properties and strength of cement-based materials [26-28]. In addition, fly ash particles may improve the workability of the fresh cement paste, thanks to their spherical particle geometry [29]. When cement-based composite materials are supported with fly ash, their performance is significantly improved and the microstructure of the composite material becomes more complex [30]. Therefore, it is important to use fly ash in concrete and cement production with respect to its role in economical, ecological, sustainability, strength, and durability factors.

\section{Materials and Method}

Portland cement clinker was used in the experimental study. Chemical properties of the clinker are given in Table $1.5 \%$ (of the weight of clinker) gypsum was used to control the setting time in the production of cement. $\mathrm{SO}_{3}$ content of gypsum was calculated to be $39.59 \%$. Standard sand was used for the preparation of the samples in compliance with the EN 196-1 standard. Fly ash obtained from Yatagan Thermal Power Plant was used as a replacement for clinker in cement production. As Yatagan fly ash has more than $10 \%$ reactive lime, it is classified under Class W (calcareous fly ash) as per TS EN 197-1. As it has more than $50 \% \mathrm{SiO}_{2}+\mathrm{AI}_{2} \mathrm{O}_{3}+\mathrm{Fe}_{2} \mathrm{O}_{3}$ content and more than $10 \% \mathrm{CaO}$, it is classified under Class $\mathrm{C}$ (highly calcareous) as per the ASTM C 618. Chemical properties of the fly ash are given in Table 1 . Chemical properties of the cement $(0,5,20$, and $35 \%)$ produced using fly ash and cement chemical are given in Table 1. Table 1 also shows the specific weight of fly ash and cements with fly ash.

Four cement chemicals were used in cement production, namely, two grinding aids and two strength enhancers for improving the early and final cement strength. The chemical additives used in cement production are commercially available and commonly used in cement factories operating in Turkey. Properties of the cement chemicals are given in Table 2.

Grinding technique was used in cement produced using clinker, limestone, and fly ash. A type bond ball mill was used to grind cement material. After placing clinker, limestone, and fly ash in the mill, chemicals were added on top of the mix. Cement chemicals with grinding aid and strength enhancing properties were used in dosages of 200 and $800 \mathrm{~g} / \mathrm{t}$, respectively. Fly ash, on the other hand, was used as a replacement for clinker at ratios of 5\%,20\%, and 35\%. A fixed grinding time of 120 minutes was used for all cement samples. Cement samples were produced in three groups. A total number of 33 cement samples, 24 of which including cement chemical and fly ash, 8 of which including cement chemical without fly ash, and 1 reference sample (without the use of fly ash and cement chemical), were prepared.

First, Blaine fineness of the cements produced was defined. Cement : aggregate : water content of the mortars was kept constant at $1: 3: 0.5$, respectively. Hardened mortar samples were taken out of the cast after 24 hours and cured in limewater at $20^{\circ} \mathrm{C}$ until the experiment day. Uniaxial compression tests were conducted on the hardened mortar samples at $2 \mathrm{nd}$, 7th, and 28th day. It was found that increased 
TABLE 1: The chemical properties of clinker, fly ash, and cement.

\begin{tabular}{|c|c|c|c|c|c|c|}
\hline$(\%)$ & OPC clinker & Fly ash & $0 \%$ & $5 \%$ & $20 \%$ & $35 \%$ \\
\hline $\mathrm{CaO}$ & 66.26 & 12.86 & 63.71 & 61.73 & 56.11 & 47.04 \\
\hline $\mathrm{SiO}_{2}$ & 21.77 & 50.41 & 19.45 & 23.49 & 27.21 & 32.08 \\
\hline $\mathrm{Al}_{2} \mathrm{O}_{3}$ & 5.6 & 22.68 & 5.55 & 6.72 & 8.93 & 11.81 \\
\hline $\mathrm{Fe}_{2} \mathrm{O}_{3}$ & 3.67 & 6.55 & 3.48 & 3.84 & 4.22 & 4.71 \\
\hline $\mathrm{MgO}$ & 1.52 & 1.19 & 1.71 & 1.50 & 1.46 & 1.40 \\
\hline $\mathrm{Na}_{2} \mathrm{O}$ & 0.27 & 0.43 & 0.22 & 0.28 & 0.30 & 0.33 \\
\hline $\mathrm{K}_{2} \mathrm{O}$ & 0.37 & 1.69 & 0.63 & 0.45 & 0.62 & 0.85 \\
\hline $\mathrm{SO}_{3}$ & 0.26 & 1.71 & 2.98 & 2.80 & 2.33 & 1.95 \\
\hline $\mathrm{Cl}$ & 0.0159 & - & 0.02 & 0.02 & 0.02 & 0.02 \\
\hline Loss on ignition & 0.10 & 1.03 & 2.11 & 0.16 & 0.28 & 0.43 \\
\hline S. $\mathrm{CaO}$ & 1.99 & & & & & \\
\hline $\mathrm{C}_{3} \mathrm{~S}$ & 52.59 & & & & & \\
\hline $\mathrm{C}_{2} \mathrm{~S}$ & 22.75 & & & & & \\
\hline $\mathrm{C}_{3} \mathrm{~A}$ & 8.64 & & & & & \\
\hline $\mathrm{C}_{4} \mathrm{AF}$ & 11.16 & & & & & \\
\hline Specific weight & & 2.15 & 3.14 & 3.08 & 2.94 & 2.81 \\
\hline
\end{tabular}

Table 2: Properties of cement additives.

\begin{tabular}{llcccc}
\hline Additive & Function of additive & Raw material & Density & pH & Color \\
\hline Grinding aid (Ö1) & Grinding aid/energy saving & Polyethanolamine acetate & 1.14 & $6-7$ & Light brown \\
Grinding aid (Ö2) & Grinding aid/energy saving & $\begin{array}{c}\text { Polyethanolamine acetate } \\
\text { modified with glycol }\end{array}$ & 1.12 & $6-7$ & Brown \\
Strength enhancer (E) & Early-age strength enhancer & Modified hydroxylamines & 1.15 & $10-12$ & Brown \\
Strength enhancer (N) & Final-age strength enhancer & Modified hydroxylamines & 1.16 & $11-12$ & Brown \\
\hline
\end{tabular}

fly ash ratio has an unfavorable effect on the workability of the cement mortars. A number of pretests were performed in order to reduce such unfavorable effect, and the use of fly ash in combination with lime was studied. In terms of workability, as the use of 35\% fly ash has an adverse impact on the mortar thickness, 35\% fly ash was used with 5\% lime dust which led to the production of the 34th cement type separate from the series. The reason behind this production was that lime, when it has the optimal fineness, reduces water need and bleeding while improving workability and strength. As particle size distribution of the cement is improved with lime addition, hardened mortar properties have also improved. Nevertheless, as lime accelerates the hydration of especially $\mathrm{C}_{3} \mathrm{~S}$ component of cement, it may improve its early-age strength. Lime forms nuclei regions for the sedimentation of $\mathrm{CH}$ crystals. With this nucleus effect, it accelerates the hydration of clinker particles, especially $\mathrm{C}_{3} \mathrm{~S}$, which translates into improved early-age strength. Therefore, fresh and hardened mortar properties are analyzed adding 5\% lime into the cement with 35\% fly ash content.

\section{Results and Discussion}

3.1. Physical Properties of Cements. Blaine fineness of the cement samples were defined as part of the experimental
TABLE 3: Results of ANOVA test for Blaine fineness (significance level- $\alpha=0.05$ ).

\begin{tabular}{lcc}
\hline Blaine fineness & $P$ value & Significance \\
\hline Cement chemical & $\mathbf{0 . 9 8 7}$ & NS \\
Dosage of chem. additive & $\mathbf{0 . 5 4 8}$ & NS \\
Fly ash & $\mathbf{0 . 0 0 0}$ & S \\
\hline
\end{tabular}

NS, not significant; S, significant.

study. ANOVA showed that the type and dosage of cement chemical used do not have an effect on the Blaine fineness. However, it was found that the ratio of fly ash used affects Blaine fineness. Results of ANOVA are given in Table 3. As shown in Table 3, the type and dosage of the cement chemical do not have an effect on the Blaine fineness as their $P$ value is larger than 0.05 . Figure 1 shows the effect of fly ash on Blaine fineness.

According to ANOVA shown in Table 3, parameters affecting the Blaine fineness were explored having identified their levels of impact. According to this impact analysis, the type $(0.987>0.05, P>\alpha)$ and dosage of chemical additive $(0.548>0.05, P>\alpha)$ do not affect the fineness of cement. The main parameter which affects the fineness of cement was found to be the fly ash content used. The reason behind the finding that fly ash has a higher impact level was that it has 


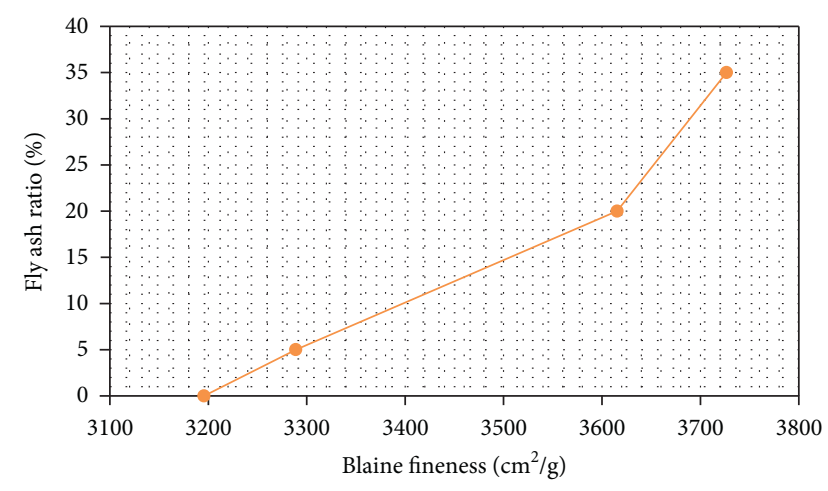

(a)

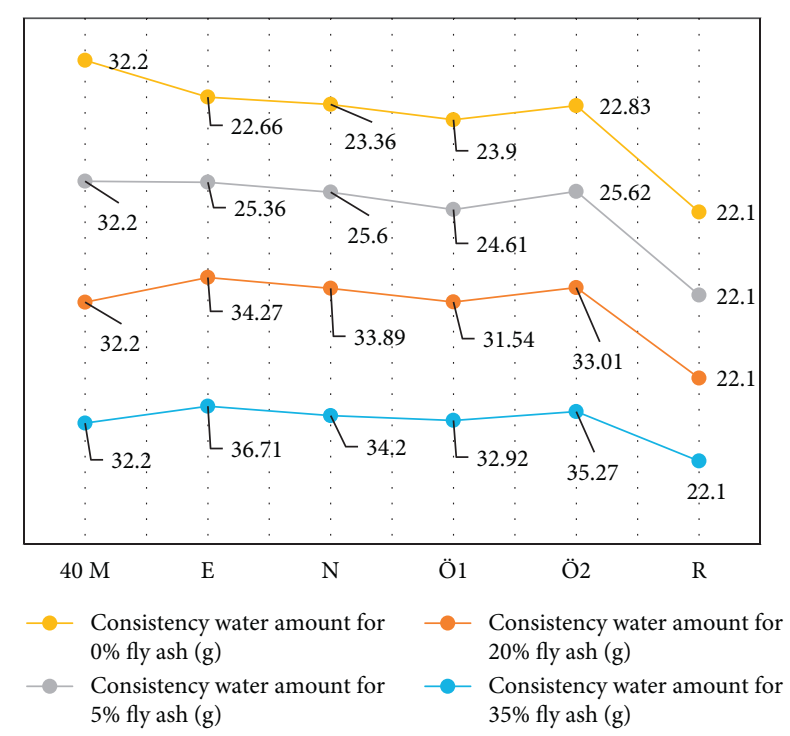

(b)

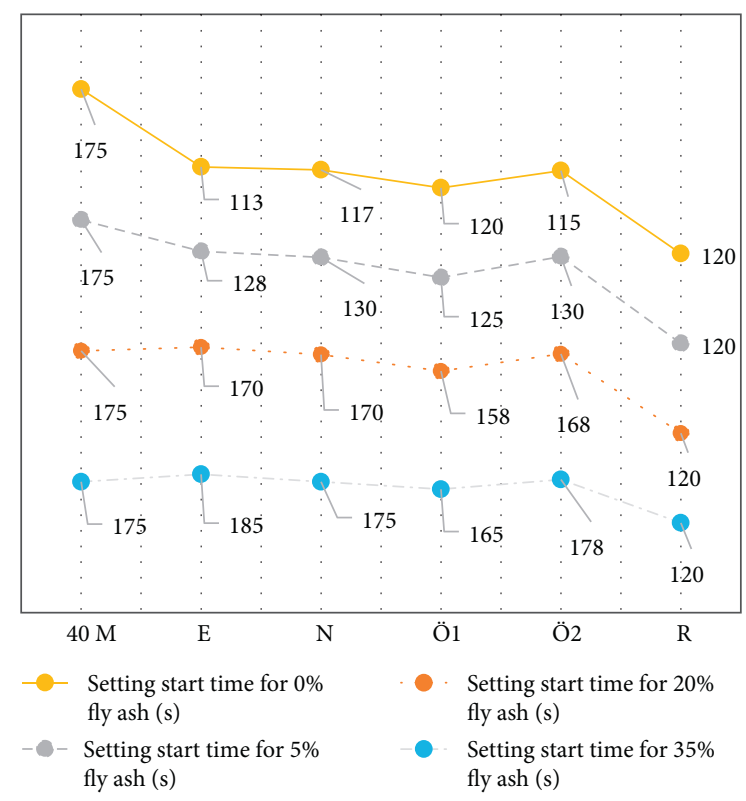

(c)

Figure 1: (a) Effect of fly ash ratio on Blaine fineness. (b) Effect of fly ash ratio on consistency water amount. (c) Effect of fly ash ratio on setting start time (s). a finer particle size distribution than clinker at the offset. Although chemical additives affect the grindability of clinkers under normal conditions, the use of mineral additives with finer particle sizes than clinker such as fly ash alters the importance of this effect. According to ANOVA analysis, the ratio of fly ash used in composite cement production directly affects the Blaine fineness values.

Blaine fineness of the cement produced without fly ash and using only cement chemical (0\%) was 7\% higher than that of the reference cement. However, it was shown that Blaine fineness increases significantly with the increasing fly ash content. Especially in the case where fly ash content was $20 \%$, Blaine fineness was found in a range between 3570 and $3660 \mathrm{~cm}^{2} / \mathrm{g}$. Where fly ash content was $35 \%$, on the other hand, Blaine fineness was found to reach up to approx. $3800 \mathrm{~cm}^{2} / \mathrm{g}$. Blaine fineness of the cement produced using $35 \%$ fly ash and 5\% lime dust (\% $40 \mathrm{M}$ ) was found to be $3770 \mathrm{~cm}^{2} / \mathrm{g}$. Increasing level of fly ash also increases the Blaine fineness. Grinding fly ash with clinker plays an important role in increasing cement fineness.

ANOVA showed that the type and dosage of cement chemical used do not have an effect on water demand and setting time (Table 4). Also showed by the ANOVA was the fact that the ratio of fly ash affects water demand and setting time. Results of the ANOVA performed for water demand and setting time are given in Table 4.

Water demand and initial setting time are increased with the increase in the fly ash content used. Initial setting time is delayed as the clinker used is reduced in weight. As a result of increased fly ash content, Blaine fineness is increased and therefore water demand of the cement paste is also increased. Increasing level of fly ash also increases the water demand of the paste. The increase in water demand, on the other hand, is another factor in increasing setting time.

Figure 1(b) shows the effect of fly ash content on water demand. Water demand of the cements produced using only cement chemical is higher than that of the reference cement. This can be explained with the fact that Blaine fineness of the reference cement is lower. When the fly ash content was $35 \%$, the water demand changed between $33.5 \%$ and $36.0 \%$. The water demand of the cement with $5 \%$ lime dust in order to offset the loss in workability due to the increased fly ash content was $32.2 \%$. Here, the use of lime dust is found to reduce the water demand notwithstanding the high Blaine fineness. Figure 1(c) shows the effect of fly ash content on initial setting time. The increase in fly ash content also increases initial setting time. Initial setting time of the cement with cement chemical and without fly ash $(0 \%)$ was shorter than that of the reference cement. Setting times of the cement with $5 \%$ lime dust ( $\% 40 \mathrm{M}$ ), on the other hand, were quite similar to those of cement with $35 \%$ fly ash content.

\subsection{Compressive Strength of Cements}

3.2.1. The Effect of Fly Ash Content on the Compressive Strength. Figure 2(a) shows the effect of fly ash content on 2-day compressive strength. Where the fly ash content is $5 \%$, it was found that compressive strength increases. Compressive 
TABLE 4: Results of ANOVA test for water demand and setting time (significance level $\alpha=0.05$ ).

\begin{tabular}{lccccc}
\hline Water demand & $P$ value & Significance & Setting time & $P$ value & Significance \\
\hline Cement chemical & 0.958 & NS & Cement chemical & $\mathbf{0 . 9 1 2}$ & NS \\
Dosage of chem. additive & 0.367 & NS & Dosage of chem. additive & $\mathbf{0 . 2 9 9}$ & NS \\
Fly ash & 0.000 & S & Fly ash & $\mathbf{0 . 0 0 0}$ & S \\
\hline
\end{tabular}

NS, not significant; S, significant.

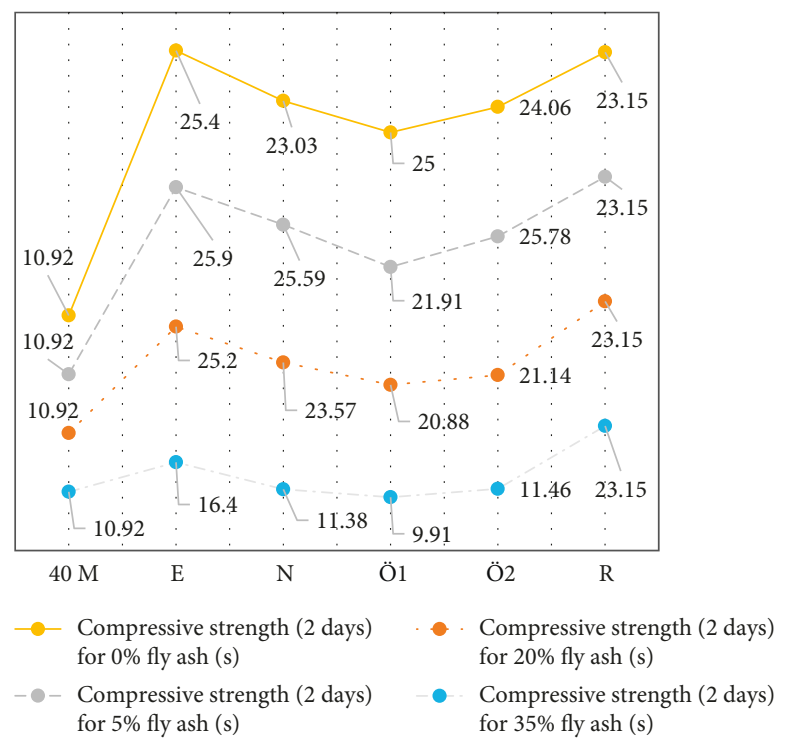

(a)

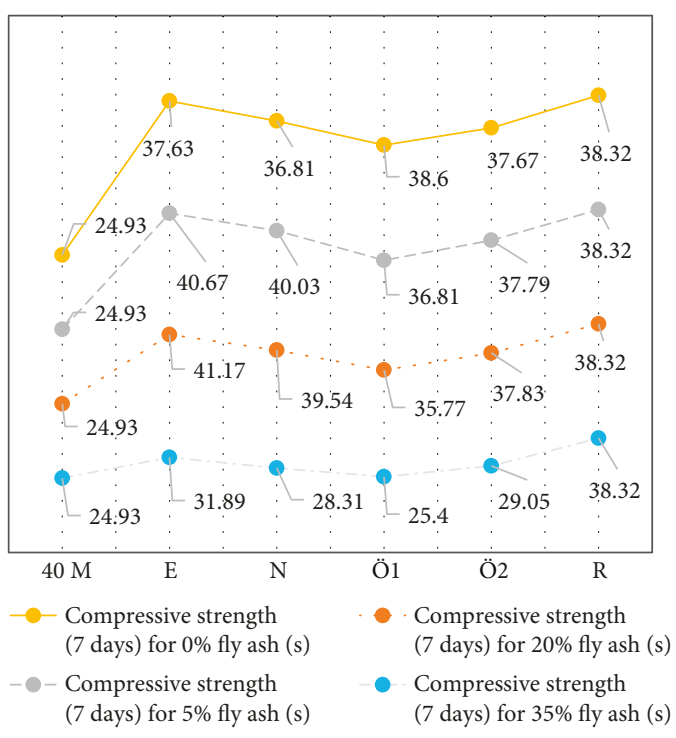

(b)

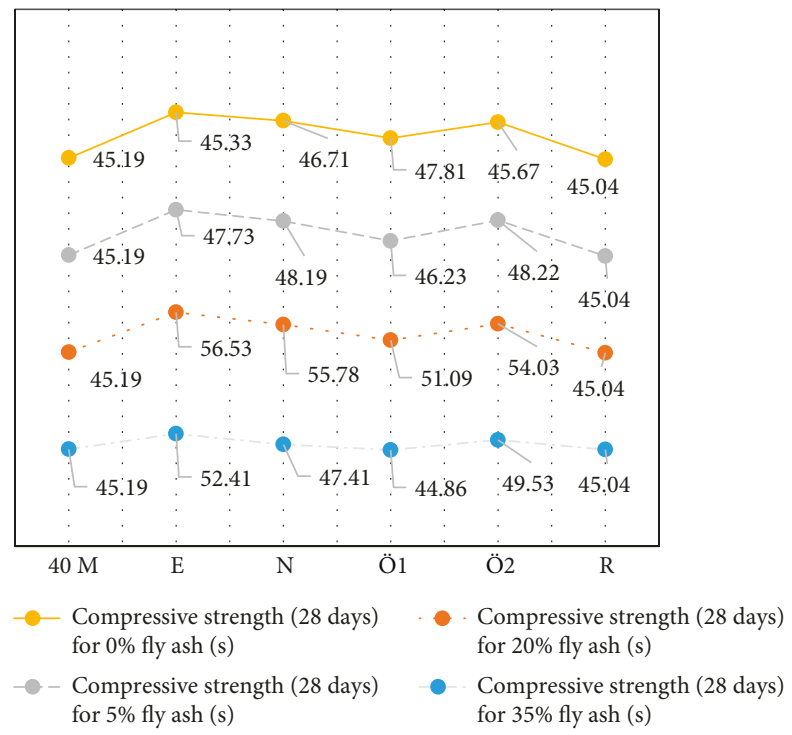

(c)

Figure 2: (a) Effect of fly ash ratio on early compressive strength (MPa). (b) Effect of fly ash ratio on 7-day compressive strength (MPa). (c) Effect of fly ash ratio on 28-day compressive strength $(\mathrm{MPa})$.

strength was in the range between 22.97 and $26.62 \mathrm{MPa}$ when the fly ash content was 5\%; 20.87-24.52 MPa when the fly ash content was 20\%; and 10.46-14.11 when the fly ash content was 35\%. 2-day compressive strength of the cement with cement chemical and without fly ash $(0 \%)$ was in the range between 22.54 and $26.19 \mathrm{MPa}$. When the fly ash content was $5 \%$, compressive strength was approx. $7.1 \%$ higher than that of the reference cement; when the fly ash content was 35\%, compressive strength was approx. $46.9 \%$ lower than that of the reference cement. Compressive 
strength of the cement produced using 35\% fly ash and 5\% lime dust (\% $40 \mathrm{M})$ was found to be $10.92 \mathrm{MPa}$.

Figure 2(b) shows the effect of fly ash content on 7-day compressive strength. Where the fly ash content is $5 \%$ and $20 \%$, it was found that 7-day compressive strength increases. 7-day compressive strength was in the range between 36.94 and $40.71 \mathrm{MPa}$ when the fly ash content was $5 \%$; $36.69-40.69 \mathrm{MPa}$ when the fly ash content was 20\%; and 26.77-30.55 when the fly ash content was $35 \%$. Where the fly ash content was $5 \%$ and $20 \%$, compressive strength was approx. $0.75 \%$ higher than that of the reference cement. However, 7-day compressive strength decreases by approx. $25.3 \%$ when fly ash content is $35 \%$. Cement with $40 \%$ mineral additive (\% $40 \mathrm{M}$ ) has a 7 -day compressive strength of $25 \mathrm{MPa}$. Cement produced with cement chemical and without fly ash is found to have a compressive strength similar to that of the reference cement.

A closer look into 28-day compressive strength values showed that these values differ greatly from 2-day and 7-day compressive strength values (Figure 2(c)). Especially, the use of $35 \%$ fly ash was found to significantly increase 28-day compressive strength. 28-day compressive strength was in the range between 45.07 and $50.11 \mathrm{MPa}$ when the fly ash content was 5\%; $51.84-56.87 \mathrm{MPa}$ when the fly ash content was $20 \%$; and 46.03-51.07 when the fly ash content was 35\%. 28-day compressive strength of the cement with cement chemical and without fly ash $(0 \%)$ was in the range between 43.86 and $48.66 \mathrm{MPa}$. However, 28-day compressive strength increases by approx. $20.7 \%$ when the fly ash content is $20 \%$. Nevertheless, compressive strength of the cement with $35 \%$ fly ash content with rather low 2-day and 7-day compressive strengths was found to increase by $7.8 \%$. 28-day compressive strength of the cement produced using 35\% fly ash and 5\% lime dust was found to be similar to that of the reference cement as shown in Figure 2(c).

Two-day compressive strength is found to be in the range between 16.38 and $24.83 \mathrm{MPa}$ when additive Ö1 is used; 16.66-25.12 MPa when additive $\mathrm{N}$ is used; $19.00-27.45 \mathrm{MPa}$ when additive $\mathrm{E}$ is used; and $15.19-23.65 \mathrm{MPa}$ when additive Ö2 is used. Affecting the early-age strength, additive E offers a 2-day compressive strength similar to that of the reference cement. Additives Ö1 and $\mathrm{N}$ offer similar 2-day compressive strength patterns. Additive Ö2, a grinding aid, was found to have negligible effect on the strength (for early ages). The fact that additive $\mathrm{E}$ is a hydroxylamine-based additive (TEA/TIPA) accelerates the hydration of $\mathrm{C}_{3} \mathrm{~S}$ available in the clinker. Similar effect was also observed when additive $\mathrm{N}$ was used. As additive $\mathrm{O} 2$ has a glycol content, it resulted in mild reductions in the compressive strength.

Additives Ö1 and $\mathrm{N}$ offer similar 28-day compressive strength patterns. Compressive strength of the additives Ö1 and $\mathrm{N}$ was in the range between 46.00 and $52.88 \mathrm{MPa}$. Compressive strength is increased by $12.1 \%$ when compared to the reference cement when additive $\mathrm{E}$ is used. When additive $\mathrm{O} 2$ is used, 28-day compressive strength was in the range between 44.13 and $50.82 \mathrm{MPa}$. Although additive Ö2 did not have a positive effect on the 2-day and 7-day compressive strength, it was found to have a significant effect on the 28-day compressive strength.

Among the grinding aids, additive Ö2 containing glycol consistently gave low compressive strength values throughout

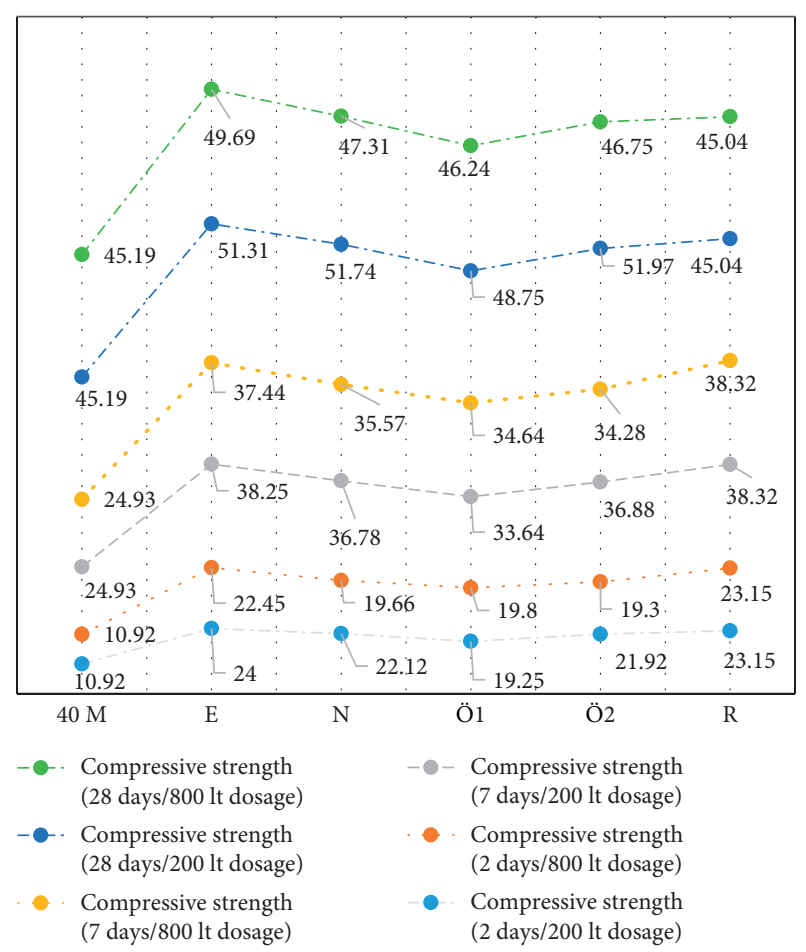

Figure 3: Effect of cement chemical additive dosage on compressive strength.

the tests. However, these differences were negligible. The literature reported increased compressive strength with the use of glycol-based additives. But this study found loss in compressive strength. It is believed that chemical properties of the clinker or the temperature in the mill during grinding may account for this result. Additive $\mathrm{E}$ with hydroxylamine, on the other hand, has a rather positive effect on both early and final strengths of the cement. Such an effect can be accounted for with the use of TEA and TIPA in strength enhancers.

\subsubsection{The Effect of Cement Chemical Dosage on Compressive} Strength. The effects of cement chemical dosage on compressive strength are shown in Figure 3. When the chemical is used at a dosage of $200 \mathrm{~g} / \mathrm{t}, 2$-day compressive strength was in the range between 18.88 and $24.76 \mathrm{MPa}$. When the chemical is used at a dosage of $800 \mathrm{~g} / \mathrm{t}, 2$-day compressive strength was approx. $12.5 \%$ lower than that of the reference cement. Figure 3 shows that increasing chemical dosage decreases compressive strength.

A closer look into 7-day compressive strength results shows that increasing chemical dosage results in decreased strength. The strength was found to be lower than that of the reference cement especially in the case where cement chemical was used at a dosage of $800 \mathrm{~g} / \mathrm{t}$. When the chemical is used at a dosage of $200 \mathrm{~g} / \mathrm{t}, 7$-day compressive strength was 38.94 MPa for the cements produced.

The effects of cement chemical dosage on 28-day compressive strength are shown in Figure 3. Increasing the cement chemical dosage has an unfavorable effect on the 28-day compressive strength as it was the case for 2-day and 7-day compressive strengths. When the chemical is used at a dosage 
TABLE 5: Unit prices of the material used in cement production (in Turkey).

\begin{tabular}{lcc}
\hline & & Unit price (\$/ton) \\
\hline Clinker & & 23.03 \\
Limestone & 14.11 \\
Fly ash & $\mathrm{E}$ & 7.11 \\
& $\mathrm{~N}$ & 0.16 \\
Chem. admix. & Ö1 & 0.19 \\
& Ö2 & 0.22 \\
Electrical energy $(\mathrm{kw} / \mathrm{h})$ & & 0.27 \\
\hline
\end{tabular}

of $200 \mathrm{~g} / \mathrm{t}$, the compressive strength was approx. 13.1\% higher than that of the reference cement. However, 28-day compressive strength increases by approx. 5.5\% when the dosage is $800 \mathrm{~g} / \mathrm{t}$. Figure 3 shows that cement with lime dust (\% $40 \mathrm{M}$ ) and reference cement have similar properties. Moreover, the reduction in compressive strength due to increased additive dosage is accounted for with the agglomeration. In some cases where excessive amounts of chemical additive are used, agglomeration may reoccur. Furthermore, increased additive dosage decreases the initial setting time. When the dosage is $800 \mathrm{~g} / \mathrm{t}$, the mortar loses its water content very fast and it hardens. The result is nonhomogeneous distribution of hydration products in the structure and crack development in the structure which are the causes of lower strength.

3.3. Cost and Optimization. Table 5 shows the unit prices (for Turkey) of clinker, limestone, fly ash, chemical additive, and electrical energy used in the cement production. Prices listed refer to the price for 1 ton.

As the cost of additives Ö 1 and Ö2 is higher in terms of chemical type used, it is more affordable to use additives $\mathrm{E}$ and $\mathrm{N}$. Increase in the amount of fly ash used often increases the cement cost. Cost analysis shows that the use of additive $\mathrm{E}$ is more beneficial. The fly ash content also plays a role in cement cost reduction (Figure 4). When the fly ash content is $20 \%$, the cost of cement is in the range between 20 and $25 \$ /$ ton. Considering also the strength of the cement as a factor, the use of $20 \%$ fly ash is the optimal solution.

An optimization study was conducted for the cement samples with fly ash content under laboratory conditions. Cement with lime was also included in this optimization process. Optimization process included only the cement with fly ash and chemical additive. Compressive strength and cost are the most important parameters in cement production. TS EN 197-1 standard imposes restriction on the 2-day and 28-day compressive strengths of cements. Therefore, the optimization process aimed for maximum level of 2-day and 28-day compressive strengths. And the cost parameter was aimed to be minimal for the cements produced. Functions used in the optimization process are shown in Table 6.

According to the parameters shown in Table 6, the most viable cement properties are obtained with $20 \%$ fly ash, additive E, and grinding at a dosage of $200 \mathrm{~g} / \mathrm{t}$. Table 7 shows

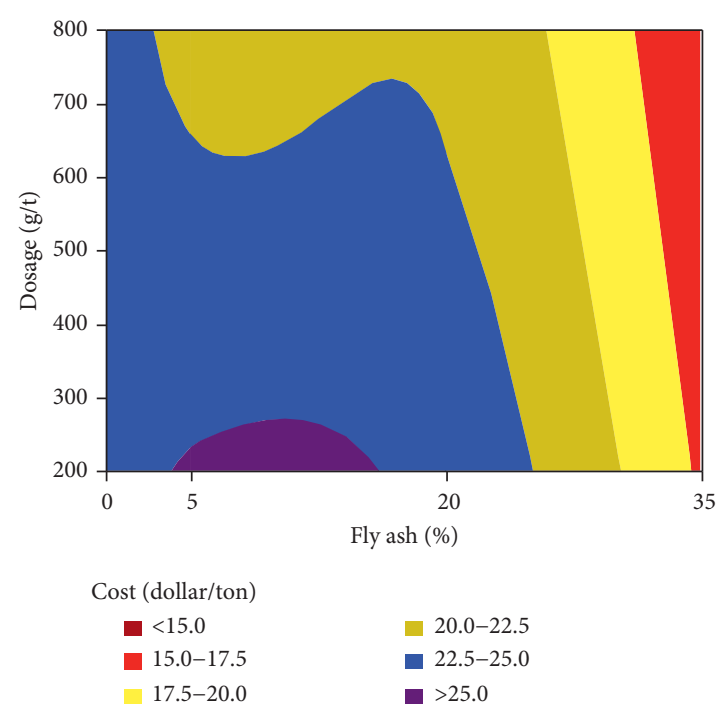

FIGURE 4: The effect of flay ash content and additive dosage on the cost (in Turkey).

TABLE 6: Optimization parameters used in cement production.

\begin{tabular}{lc}
\hline Objective function & Characteristic \\
\hline 2-day compressive strength $(\mathrm{MPa})$ & Maximize \\
28-day compressive strength $(\mathrm{MPa})$ & Maximize \\
Cost $(\$)$ & Minimize \\
\hline
\end{tabular}

TABLE 7: A comparison of the reference cement and the optimal cement.

\begin{tabular}{lccc}
\hline & $\begin{array}{c}\text { Reference } \\
\text { cement }\end{array}$ & $\begin{array}{c}\text { Optimal } \\
\text { cement }\end{array}$ & $\begin{array}{c}\text { Difference } \\
(\%)\end{array}$ \\
\hline $\begin{array}{l}\text { 2-day } \\
\text { compressive } \\
\text { strength }(\mathrm{MPa})\end{array}$ & 23.15 & 25.66 & 10.8 \\
$\begin{array}{l}\text { 28-day } \\
\text { compressive } \\
\text { strength }(\mathrm{MPa})\end{array}$ & 45.04 & 56.57 & 25.6 \\
\begin{tabular}{l} 
Cost $(\$)$ \\
\hline
\end{tabular} & 26.78 & 24.19 & 9.7 \\
\hline
\end{tabular}

a comparison of the cement produced using the abovementioned properties with the reference cement.

\section{Results}

This study analyzed the production of type CEM II A-B/W cement with the replacement of Portland cement clinker with Class C fly ash at ratios of 5\%, 20\%, and 35\%. During the cement grinding process, 4 different cement chemicals were included at dosages of 200 and $800 \mathrm{~g} / \mathrm{t}$. The following findings were obtained as a result of this study:

(1) The impact of the type and dosage of cement chemical on the water demand and setting times was insignificant. The fly ash content did not affect setting time and water demand. Increase in the fly ash 
content also increases water demand. Nevertheless, increase in fly ash content also increases initial setting time and final setting time.

(2) Increasing fly ash content directly affects the Blaine fineness of cements. Cements with approx. $3800 \mathrm{~cm}^{2} / \mathrm{g}$ Blaine fineness were produced using fly ash at a ratio of $35 \%$. Blaine fineness of the cement produced without fly ash and using only cement chemical was $7 \%$ higher than that of the reference cement.

(3) An increase in the fly ash content decreases early-age strength (2 and 7 days); however, such an increase has a favorable impact on the final-age strength. Especially, the use of $20 \%$ fly ash makes it possible to produce cement with $52.5 \mathrm{~N}$ strength class. Where the fly ash content is $35 \%$, it is possible to produce cement with $42.5 \mathrm{~N}$ strength class. Moreover, using $35 \%$ fly ash content, it was possible to obtain cement complying with $52.5 \mathrm{~L}$ strength class for type CEM III cements.

(4) Additives E and N (strength enhancers) had a positive impact on the mechanical properties of the cements. However, increasing the additive dosage decreases compressive strength of cements. The use of strength enhancers offers better results in cements with fly ash.

(5) As a result, it is possible to produce highperformance cement using fly ash. Especially, the use of fly ash at the ratios of $20 \%$ and $35 \%$ plays an important role in reducing $\mathrm{CO}_{2}$ emissions. The use of strength enhancers is more suitable in cement with fly ash.

\section{Conflicts of Interest}

The authors declare that they have no conflicts of interest.

\section{References}

[1] A. Jankovic, W. Valery, and E. Davis, "Cement grinding optimisation," Minerals Engineering, vol. 17, no. 11-12, pp. 1075-1081, 2004.

[2] H. Dundar, H. Benzer, N. A. Aydogan et al., "Simulation assisted capacity improvement of cement grinding circuit: case study cement plant," Minerals Engineering, vol. 24, no. 3-4, pp. 205-210, 2011.

[3] H. Benzer, L. Ergün, M. Öner, and A. J. Lynch, "Simulation of open circuit clinker grinding," Minerals Engineering, vol. 14, no. 7, pp. 701-710, 2001.

[4] G. Atesok, M. Ozer, F. Boylu, and H. Dincer, "The effect of anionic dispersants on grindability of different rank coals," International Journal of Mineral Processing, vol. 77, no. 4, pp. 199-207, 2005.

[5] J. J. Assaad, "Industrial versus Laboratory clinker processing using grinding aids (scale effect)," Advances in Materials Science and Engineering, vol. 2015, Article ID 938176, 12 pages, 2015.

[6] J. J. Assaad and C. A. Issa, "Effect of clinker grinding aids on flow of cement-based materials," Cement and Concrete Research, vol. 63, pp. 1-11, 2014.
[7] V. S. Ramachandran, "Hydration of cement-role of triethanolamine," Cement and Concrete Research, vol. 6, no. 5, pp. 623-631, 1976.

[8] Z. Heren and H. Ölmez, "The influence of ethanolamines on the hydration and mechanical properties of Portland cement," Cement and Concrete Research, vol. 26, no. 5, pp. 701-705, 1996.

[9] M. Ichikawa, M. Kanaya, and S. Sano, "Effect of triisopropanolamine on hydration and strength development of cements with different character," in Proceedings of the 10th International Congress on the Chemistry of Cement, vol. 3 , p. 3iii005, Gothenburg, Sweden, 1997.

[10] O. Altun, H. Benzer, A. Toprak, and U. Enderle, "Utilization of grinding aids in dry horizontal stirred milling," Powder Technology, vol. 286, pp. 610-615, 2015.

[11] T. Zhang, J. Gao, and J. Hu, "Preparation of polymer-based cement grinding aid and their performance on grindability," Construction and Building Materials, vol. 75, pp. 163-168, 2015.

[12] H. Li, J. Zhao, Y. Huang et al., "Investigation on the potential of waste cooking oil as a grinding aid in Portland cement," Journal of Environmental Management, vol. 184, pp. 545-551, 2016.

[13] Y. Zhang, A. Fei, and D. Li, "Utilization of waste glycerin, industry lignin and cane molasses as grinding aids in blended cement," Construction and Building Materials, vol. 123, pp. 785-791, 2016.

[14] T. Heller, T. Müller, and D. Honert, "Cement additives based on PCE," ZKG International, vol. 64, no. 2, pp. 40-48, 2011.

[15] E. Sakai, A. Ishida, and A. Ohta, "New trends in the development of chemical admixtures in Japan," Journal of Advanced Concrete Technology, vol. 4, no. 2, pp. 211-223, 2006.

[16] J. Plank, E. Sakai, C. W. Miao, C. Yu, and J. X. Hong, "Chemical admixtures-chemistry, applications and their impact on concrete microstructure and durability," Cement and Concrete Research, vol. 78, pp. 81-99, 2015.

[17] Z. Sun, H. Yanga, L. Shui et al., "Preparation of polycarboxylate-based grinding aid and its influence on cement properties under laboratory condition," Construction and Building Materials, vol. 127, pp. 363-368, 2016.

[18] E. Ghiasvand and A. A. Ramezanianpour, "Effect of grinding method and particle size distribution on long term properties of binary and ternary cements," Construction and Building Materials, vol. 134, pp. 75-82, 2017.

[19] K. H. Yang, Y. B. Jung, M. S. Cho, and S. H. Tae, "Effect of supplementary cementitious materials on reduction of $\mathrm{CO}_{2}$ emissions from concrete," Journal of Cleaner Production, vol. 103, pp. 774-783, 2015.

[20] T. Sato and J. J. Beaudoin, "Effect of nano- $\mathrm{CaCO}_{3}$ on hydration of cement containing supplementary cementitious materials," Advances in Cement Research, vol. 23, no. 1, pp. 33-43, 2011.

[21] Z. Liu, Y. Zhang, and Q. Jiang, "Continuous tracking of the relationship between resistivity and pore structure of cement pastes," Construction and Building Materials, vol. 53, pp. 26-31, 2014.

[22] R. Snellings, "Assessing, understanding and unlocking supplementary cementitious materials," RILEM Technical Letters, vol. 1, p. 50, 2016.

[23] L. Lam, Y. L. Wong, and C. S. Poon, "Degree of hydration and gel/space ratio of high-volume fly ash/cement systems," Cement and Concrete Research, vol. 30, no. 5, pp. 747-756, 2000.

[24] P. Hou, S. Kawashima, D. Kong, D. J. Corr, J. Qian, and S. P. Shah, "Modification effects of colloidal nanoSiO ${ }_{2}$ on 
cement hydration and its gel property," Composites Part B: Engineering, vol. 45, no. 1, pp. 440-448, 2013.

[25] M. Ahmaruzzaman, "A review on the utilization of fly ash," Progress in Energy and Combustion Science, vol. 36, no. 3, pp. 327-363, 2010.

[26] J. David Raja Selvam, D. S. Robinson Smart, and I. Dinaharan, "Microstructure and some mechanical properties of fly ash particulate reinforced AA6061 aluminum alloy composites prepared by compocasting," Materials \& Design, vol. 49, pp. $28-34,2013$.

[27] R. Feldman, L. R. Prudencio, and G. Chan, "Rapid chloride permeability test on blended cement and other concretes: correlations between charge, initial current and conductivity," Construction and Building Materials, vol. 13, no. 3, pp. 149154, 1999.

[28] S. W. M. Supit and F. U. A. Shaikh, "Durability properties of high volume fly ash concrete containing nano-silica," Materials and Structures, vol. 48, no. 8, pp. 2431-2445, 2014.

[29] N. Neithalath and J. Jain, "Relating rapid chloride transport parameters of concretes to microstructural features extracted from electrical impedance," Cement and Concrete Research, vol. 40 , no. 7, pp. 1041-1051, 2010

[30] Z. Liu, D. Xu, and Y. Zhang, "Experimental investigation and quantitative calculation of the degree of hydration and products in fly ash-cement mixtures," Advances in Materials Science and Engineering, vol. 2017, Article ID 2437270, 12 pages, 2017. 


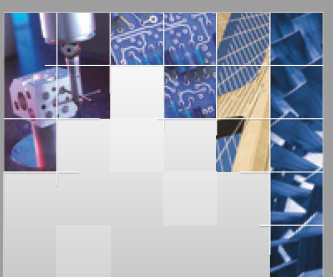

\section{Enfincering}
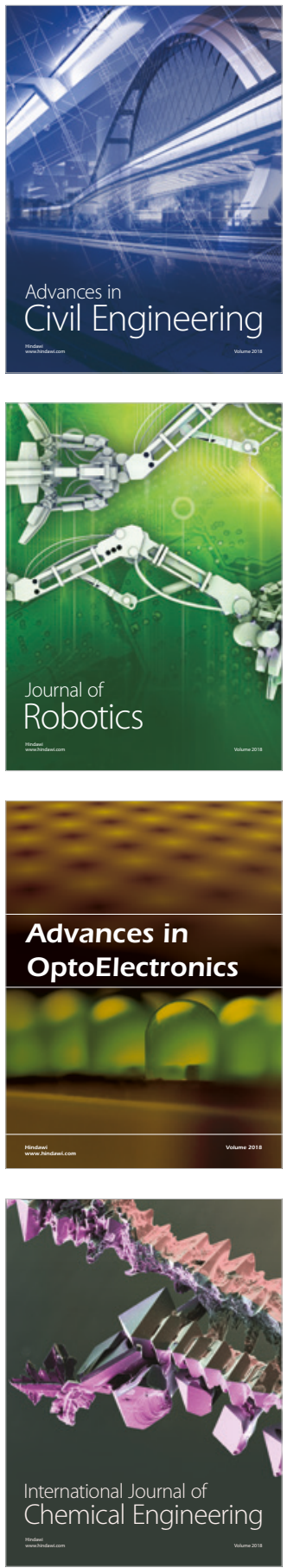

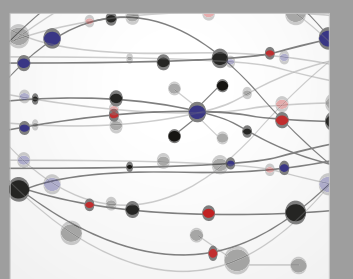

\section{Rotating \\ Machinery}

The Scientific World Journal

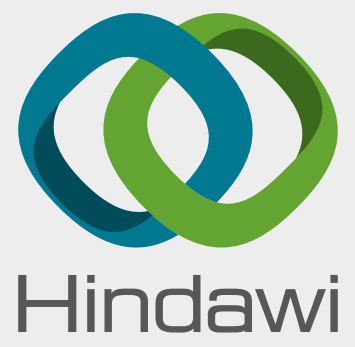

Submit your manuscripts at

www.hindawi.com
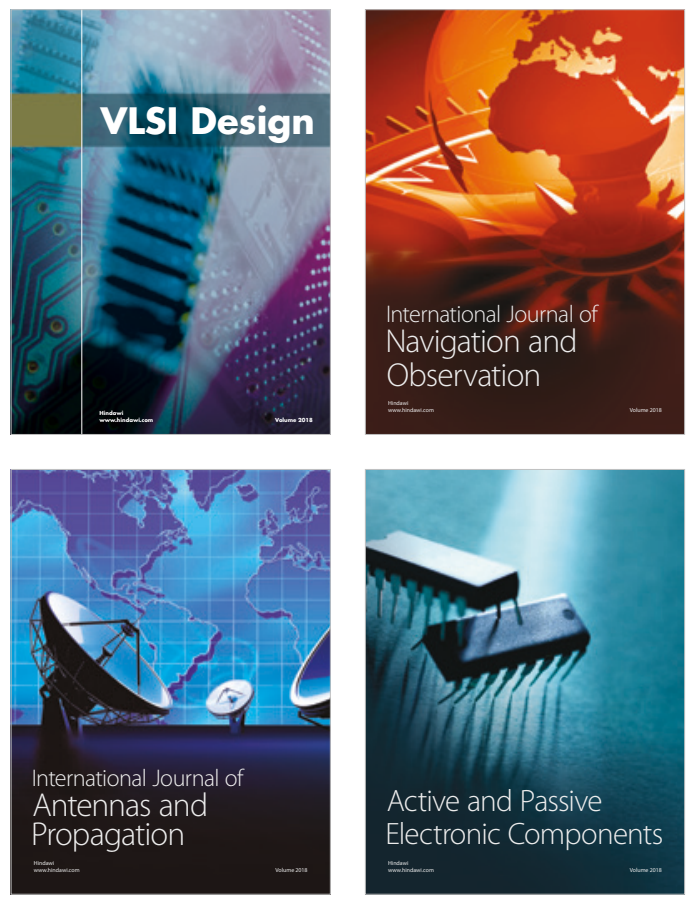
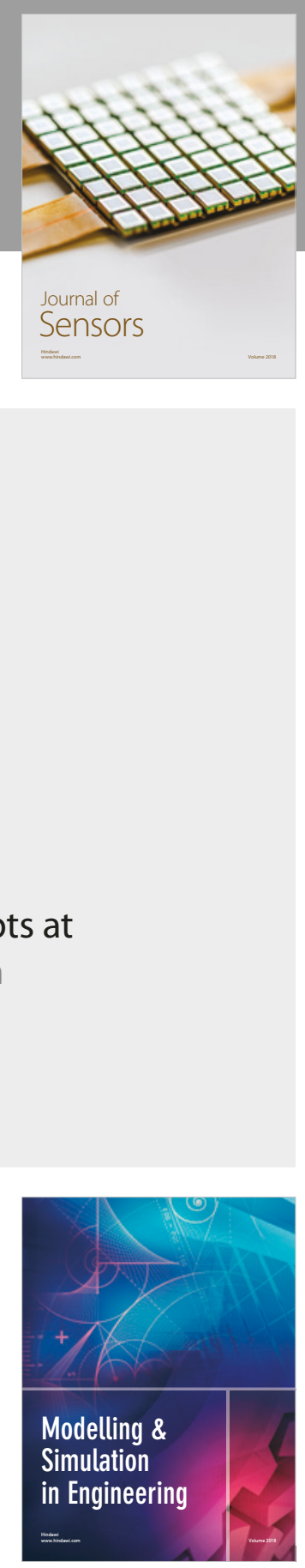

\section{Advances \\ Multimedia}
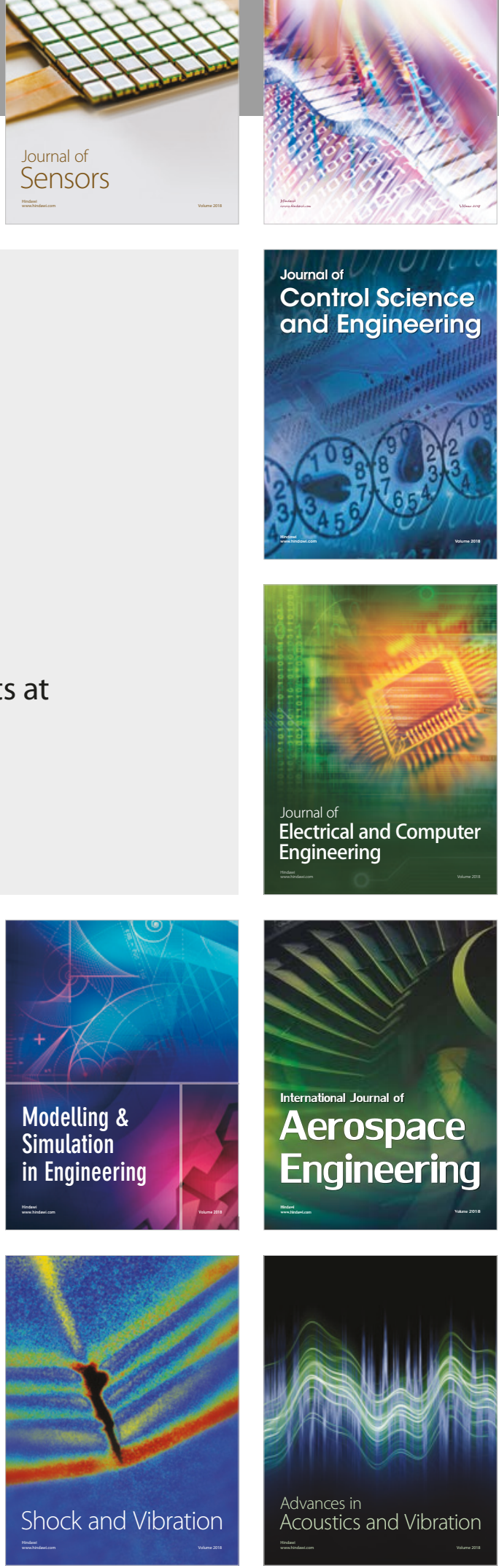